\title{
Investigation of Groundwater Contamination from Akanran Open Waste Dumpsite, Ibadan, South-Western Nigeria, using Geoelectrical and Geochemical Techniques
}

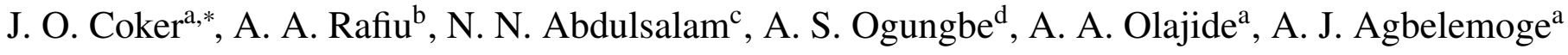 \\ ${ }^{a}$ Department of Physics, Olabisi Onabanjo University, Ago - Iwoye, Ogun State, Nigeria \\ ${ }^{b}$ Department of Physics, Federal University of Technology, Minna, Niger State, Nigeria \\ ${ }^{c}$ Department of Physics, University of Abuja, Nigeria \\ ${ }^{d}$ Department of Physics, Lagos State University, Nigeria
}

\begin{abstract}
In recent times, large waste is produced especially in an urban area due to population with careless handling which calls for worries. Hence, the study determines the effect of Akanran dumpsite on the groundwater quality for drinking and domestic purposes. It employs the electrical resistivity and geochemical methods. The Wenner configuration was adopted with constant electrode separation ranging from 5 to $25 m$ to acquire five profiles within and outside the dumpsite and processed using DIPROWIN 4.01 software. Three (3) Soil and water samples were collected and analysed. The 2-D pseudosection revealed a very low resistivity value of $9.2 \mathrm{ohm}$-meter and is suspected to be leachate infiltration which migrates to a depth of $7 \mathrm{~m}$. The results of soil analysis show that clay ranges between $9.61-18.8 \%$., silt between $9.27-19.7 \%$ and an average bulk density of 1.48 (relatively high for a sandy loam) which suggests that infiltration of the leachate is minimal. The pH of the water sample analysis obtained is 6.9 , suggesting acidic concentrates in the groundwater of the study area. However, this pH value for drinking water is within the permissible level of $6.5-8.5$ indicating that the groundwater in the study area is suitable for drinking and also for other purposes. A Nitrate level of $2.56 \mathrm{mg} / \mathrm{l}$ in the water sample falls within $50.0 \mathrm{mg} / \mathrm{l}$, and nitrite level of $0.09 \mathrm{mg} / \mathrm{l}$ which is moderate when compared to the permissible level limit of $0.20 \mathrm{mg} / \mathrm{l}$. The concentration of heavy metals in a hand-dug well sample from Akanran dumpsite are $\mathrm{Zn}(1.81 \mathrm{mg} / \mathrm{l}), \mathrm{Cu}(0.38 \mathrm{mg} / \mathrm{l})$, $\mathrm{Cr}(0.003 \mathrm{mg} / \mathrm{l})$ which are within the permissible level limit and $\mathrm{Pb}(0.21 \mathrm{mg} / \mathrm{l})$ which recorded high metal concentration which may suggest that the dumpsite contain waste metals which may leach down the soil. In conclusion, the groundwater in the area of the survey is safe for drinking, domestic purpose and agricultural use; and there is high toxicity level and possible leaching of lead.
\end{abstract}

DOI:10.46481/jnsps.2021.166

Keywords: Contaminants, Geochemical, Leachate, Resistivity, Dumpsite

Article History :

Received: 11 February 2021

Received in revised form: 10 May 2021

Accepted for publication: 13 May 2021

Published: 29 May 2021

(c)2021 Journal of the Nigerian Society of Physical Sciences. All rights reserved. Communicated by: O. J. Abimbola

${ }^{*}$ Corresponding author tel. no: +2347032261146

Email address: coker.joseph@oouagoi woye.edu.ng (J. O. Coker)

\section{Introduction}

To get rid of waste generated, many dumpsites around the country have been overfilled and causing environmental pollution. Contamination of groundwater is a major issue in a dumpsite, as leachate may infiltrate the aquifer. The quantity and 
the concentration of the toxic fluid (leachate and gases) produced depend on the age of the landfill site, types and amount of soil vegetation cover, the geology of the area, amount of precipitation, types of wastes, and the inflow of groundwater [1]. Leachate from open dumpsites and landfills usually contain chemical and biological constituents [2].

The leachate flows downward and outward from the dumpsite and this downward flow may threaten springs at the periphery of the landfill [3]. As leachate moves downward, it mixes with the groundwater in between the pore-spaces within the soil, and this moves through the groundwater's path as plumes of contaminated groundwater. Leachate generated in a dumpsite is always associated with a high concentration of ions which results in very low resistivities of host rocks or formation [4]. Therefore, the direct current resistivity method, induced polarization, and very low-frequency Electromagnetic method are parts of the methods that could be used to effectively map leachate plume zones [5].

Water pollutants come not only from urban and municipal wastewater discharges, but also from non-point sources, some of which are not perceived as such. Most of the non-point sources have been initially recognised as such by groundwater experts [6] who realized that soil (urban or rural) was an important means of transporting pollution to ground and surface water through complex interactions [7]. Various hazards are associated with the waste dumpsites, e.g. surface water contamination, groundwater contamination, bad smell or odour, release of greenhouse gases, accidental hazard caused by fire, slope instability, loss of vegetation, soil contamination and bird-hit [8]. Similarly, many of the above mentioned hazards were associated with Akanran dumpsite, such as bad odour, loss of vegetation and electronic waste.

Escherichia coli, better known as E. coli, are a common and diverse group of bacteria found in food, the environment, and in the intestines of both people and certain warm-blooded animals. While E. coli has a bad reputation, the truth is that most strains of E. coli are actually harmless. And some strains are essential to good health, according to the Centers for Disease Control and Prevention (CDC); E. coli produces vitamin K and vitamin B12, and maintains a protective space in your gut for other beneficial bacteria.

Resistivity imaging is relatively less expensive, non-invasive, and has proved very useful in environmental and engineering problems such as investigation of landfill sites and detection of bedrock contamination [9]. The integrated geophysical methods including the 2-D resistivity survey, VLF-EM, and seismic survey have provided major tools in environmental studies [10]. Leachate from the dumpsite always polluted the groundwater, most especially the hand-dug wells situated near the dumpsites, thereby putting the health of the people under threat.

The impact of solid waste disposal on the groundwater within the vadose and saturated zone of two dumpsites namely AbaEku and Ajakannga in Ibadan Metropolis was investigated by [11] using Vertical Electrical Sounding (VES) to determine the depth and thickness of subsurface layers. The result from the VES data gives a qualitative lithology of topsoil and clayey soil (aquitard) which has a low resistivity zone ; $100 \mathrm{Ohm}-\mathrm{m}$, un- derlain by higher resistive basement.

A geophysical investigation involving 2D resistivity survey on Aba Eku dump site in Southwestern Nigeria was carried out by Ganiyu et al. [12] with a view to map the conductive leachate plume and extent of migration of leachate plumes in the subsurface for possible groundwater contamination. The 2D resistivity survey was carried out using Wenner array configuration of electrode spacing distance ranging from $5-25 \mathrm{~m}$. The inverse resistivity models of the subsurface from $2 \mathrm{D}$ imaging revealed low resistivity value less than $10 \Omega m$ suspected to be leachate infiltration. The extent of leachate migration was up to a depth of about $4 \mathrm{~m}$, an indication that the underlying layer has a greater risk of contamination by leachate and decomposed solid waste materials.

In this study, electrical resistivity and geochemical studies were carried out on an open waste dumpsite in Aba-Eku (Akanran), Ibadan, to ascertain the impact of leachate on the groundwater system. The specific objectives are; to examine the health implication of the leachate generated in the landfill on the inhabitants living near the study area through geochemical analyses of water and soil samples around the study area and to evaluate the groundwater conditions for drinking and domestic purposes.

\subsection{Location and the Geologic Settings of the Study Area}

Ibadan is Africa's largest indigenous settlement located in Southwestern Nigeria with a population of over 2.6 million people according to the 2006 National Census survey. Ibadan lies approximately on longitude $3^{\circ} 35^{\prime}$ to $4^{\circ} 10^{\prime} E$ and latitude $7^{\circ} 20^{\prime}$ to $7^{\circ} 40^{\prime} \mathrm{N}$ at about $145 \mathrm{~km}$ northeast of Lagos. In Ibadan city, solid waste generation is on the increase. The city currently generates about $1,618,293 \mathrm{~kg}$ of solid waste daily with about $10 \%$ of this evacuated by the Oyo State Waste Management Authority [12] The two local climates experience in Ibadan are the dry season from November to February and the rainy season which runs from March to October, and the temperature ranges between $21{ }^{\circ} \mathrm{C}$ and $35^{\circ} \mathrm{C}$. Ibadan is a part of the basement complex of the geological setting of Southwestern Nigeria (Fig. 1). The basement complex rocks consist of few intrusions of porphyries of the Jurrasic age, the metamorphic rocks of Precambrian age, and granites. Aba Eku is mainly underlain by the quartzite and quartz schist (Fig. 1). The common rocks in many parts of Ibadan are the weathered regoliths. In Ibadan, over $75 \%$ of the rocks are banded gneiss while augen gneisses and quartzites share the remaining in about equal percentages $[13,14]$.

\section{Materials and Method}

The 2-D resistivity technique is widely used in the investigation of contaminants at both the saturated and unsaturated zones [16]. To take a measurement, current was injected through the outer current electrode pair into the ground which generated a potential difference measured by the inner potential electrodes. 


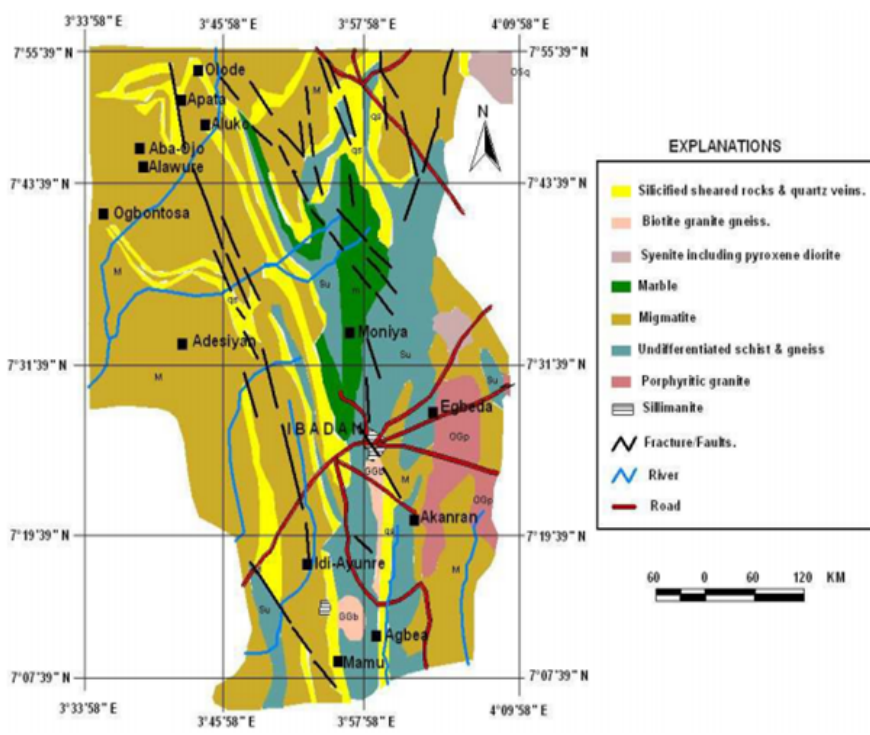

Figure 1. A Generalized geological map of Ibadan showing Akanran Dumpsite [15].

Two dimensional (2D) electrical resistivity surveys were carried out within the dumpsite using Campus Tigre model resistivity meter. Four (4) profiles (P1, P2, P3, and P5) were mapped out within the refuse dumpsite and a control profile (P4) using the Wenner array configuration. Fig. 2 shows the data acquisition map for Akanran dumpsite. The electrode separation distance for each traverse ranged from $\mathrm{a}=5 \mathrm{~m}$ to $\mathrm{a}=$ $25 \mathrm{~m}$ with a station interval of $5 \mathrm{~m}$. The traverse length ranged from $100 \mathrm{~m}$ to $150 \mathrm{~m}$. The Wenner array has the strongest signal strength when compared with other arrays and its geometric factor is $2 \pi a$ [12].

The acquired field data was processed using the DIPROfWIN software. The software iterated the data before giving out the final Resistivity structure.

Soil influences the rate of leachate migration hence; in this study, soil samples were taken from the dumpsite and subjected to sieve analysis to determine its textural characteristics and physical properties. The in-situ soil samples were collected at three different points within the study area and another three samples were collected outside the dumpsite serving as the control. At each sample point, two samples were collected from 0$20 \mathrm{~cm}$ and 20-40 $\mathrm{cm}$ depths using a soil auger and a cylindrical core of diameter $5 \mathrm{~cm}$ and height $5 \mathrm{~cm}$. The collected soil samples were allowed to pass through $2.00 \mathrm{~mm}$ sieve to remove any plant materials after been air-dried and a modified Boyoucos hydrometer method described by Grossman and Reinsch [17] was used to determine the properties of sand, silt, and clay. The soil textural class was estimated using a textual triangle. Bulk density [17] was evaluated by using equations 1,2 and 3

$$
P_{b}=\frac{M_{s}(g)}{V_{b}\left(\mathrm{~cm}^{3}\right)}
$$

where $P_{b}$ is the soil bulk density $\left(\mathrm{gcm}^{-3}\right) ; M_{s}=$ the mass of oven-dried soil $(g)$ and $V_{b}=$ the volume of the soil/cylindrical core $\left(V_{b}=\pi r^{2} h ; r\right.$ being the internal diameter and $h$ the height

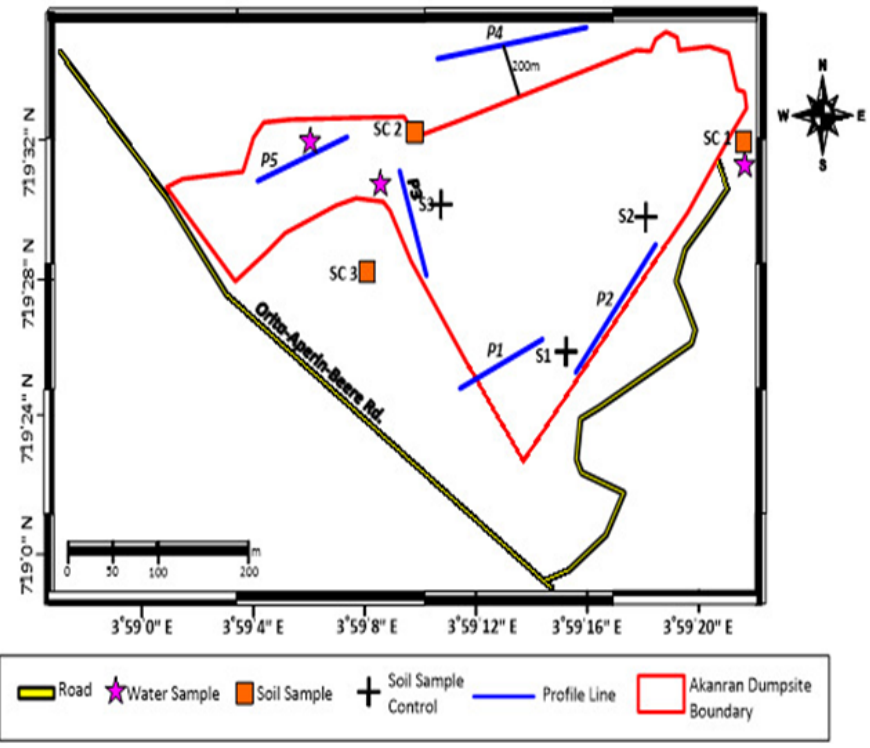

Figure 2. Map of Akanran dumpsite showing the distributions of the 2D Electrical Resistivity Profiles, Water sample, and Soil sample points.

of the cylindrical core). Total porosity $\left(T_{P}\right)$ is:

$$
T_{b}=\left[\frac{1-P_{p}}{P_{s}}\right] \times 100
$$

where $T_{p}=$ the total porosity (\%); $P_{b}=$ the soil bulk density $\left(\mathrm{Mgm}^{-3}\right) ; P_{s}=$ the soil particle density with a constant value of $2.65 \mathrm{Mgm}^{-3}$. According to Reynolds [5] and transposed Darey's equation for a vertical flow of liquid:

$$
K_{s}=\frac{Q L}{t A(\Delta H)}
$$

where $Q=$ the volume of water that flows through the soil column at equilibrium; $A$ is the cross-sectional area of flow (soil core) through the soil column; $t$ is the time interval $(h r) ;$.$L is$ the length of soil column $(\mathrm{cm})$ and $\Delta H$ is the hydraulic head $(\mathrm{cm})$.

$$
\Delta H=L+h_{w}
$$

where $h_{w}$ is the head of water above the soil column.

$50 \mathrm{~g}$ air-dry soil (; $2 \mathrm{~mm}$ ) was weighed into a $100 \mathrm{~mL}$ glass beaker and $50 \mathrm{~mL}$ distil water added by the volumetric flask. The mixture was done in a glass rod and stirred every $10 \mathrm{~min}$ utes. The $\mathrm{pH}$ meter was calibrated and the combined electrodes were put in suspension (about $3 \mathrm{~cm}$ deep) and read after $30 \mathrm{sec}$ onds with one decimal.

Water samples were collected at three different points and analysed to determine the E. coli, total organic carbon, total dissolved solids, nitrate, nitrite, $\mathrm{COD}, \mathrm{pH}$, sodium (Na), sulphate $\left(\mathrm{SO}_{4}\right)$, Chromium $(\mathrm{Cr})$, copper $(\mathrm{Cu})$, Lead $(\mathrm{Pb})$ and zinc (Zn). Apparatus which include $\mathrm{pH}$ meter with Combined Electrode, Beakers: polyethylene, TFE beakers, plastic, Wash bottle, Reagents were used. Total dissolved solids are given in equation 4

$$
\text { Total Dissolved Solids }=\left(\frac{m g}{L}\right) \frac{W_{t(d+s)}-W_{t(d)}}{V} \times 1000(4)
$$


where $W_{t(d+s)}=$ Weight of dish plus solids $(m g), W_{t(d)}=$ Weight of dish before use $(\mathrm{mg}), \mathrm{s}=$ solids $(\mathrm{mg})$ and $\mathrm{V}=$ volume of water sample used for measurement $(m L)$.

0.5-1.0 g air-dry soil $(0.15 \mathrm{~mm})$ was weighed into a 300 $m L$ calibrated digestion tube, $3 \mathrm{~mL}$ concentrated $\mathrm{HNO}_{3}$ added, and swirled, and then the tubes were placed in the rack. The heavy metals such as $\mathrm{Cu}, \mathrm{Zn}, \mathrm{Fe}, \mathrm{Mn}, \mathrm{Pb}, \mathrm{Cr}, \mathrm{Cd}, \mathrm{Ni}$, and $\mathrm{Co}$ were determined using Atomic Absorption Spectrophotometer. All statistical analyses were conducted using the replicated data collected for water and soil samples. Using the Duncan Multiple Range Test (DMRT) at $5 \%$ probability, the Mean of soil samples was differentiated.

\section{Results and Discussion}

The inverted 2-D resistivity pseudosections are hereby presented in Figures 3 to 7. Profile 1 (Fig. 3) shows the layers of the subsurface, the topsoil has a low resistivity values ranging between 3 to $11 \Omega m$ at depths 0 to $5 \mathrm{~m}$.

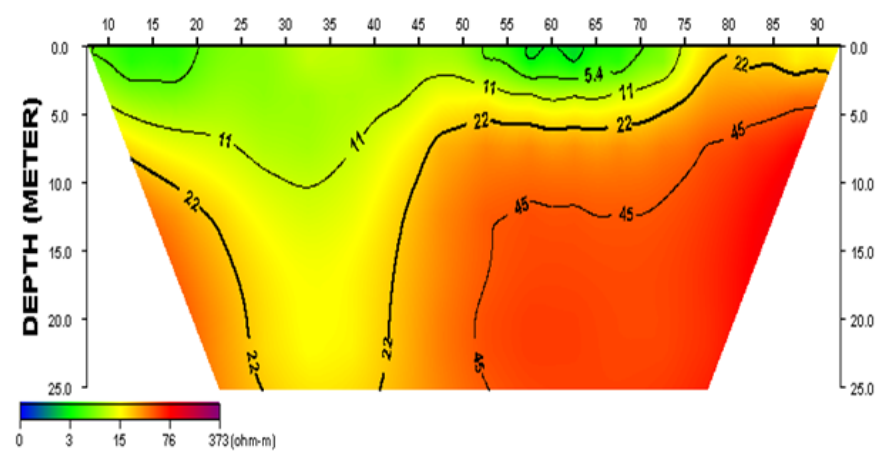

Figure 3. 2-D Electrical resistivity pseudosection for profile 1.

The thin weathered layer which underlies the first layer has true resistivity value between $22-76 \Omega m$ indicating clayey material. The last layer has resistivity values between $76-373 \Omega m$ at depths $10-25 \mathrm{~m}$. Although between the distances of $25 \mathrm{~m}$ $45 m$ exists a depression to a depth of about $16 m$ which could be a fractured zone. The uneven nature of the top of the basement rock is due to uneven weathering around the area investigated.

Figure 4 presented profile 2 indicating extensive contamination of topsoil (regolith) from the ground surface to $5 \mathrm{~m}$ as the resistivity of the topsoil is less than $100 \Omega m$ over the horizontal extent. An intermediate resistivity layer occurred at the intermediate depth zone between 5 and $10 \mathrm{~m}$ indicating the presence of lateritic clay at the topsoil (regolith) with the resistivity ranging from $100-141 \Omega m$. A thick layer with a comparatively high resistivity above $423 \Omega m$ was also observed below the layers of low to intermediate resistivity rocks. Bedrock resistivity is higher $400 \Omega m$ at shallow depth. The contaminant here is limited to the topsoil because the basement is close to the surface so; the plume cannot migrate to the subsurface but can flow within the topsoil and migrate to another location.

Figure 5 shows the inverted 2D Electrical resistivity section for profile 3 conducted North-western part of the dumpsite showed that the topsoil is extensively contaminated at a horizontal distance 10 - $45 \mathrm{~m}$ with resistivity values lower than 22

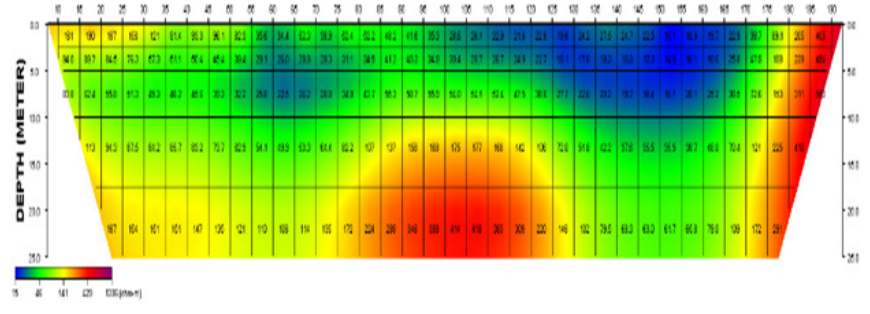

Figure 4. 2-D Electrical resistivity pseudosection for profile 2.

$\Omega m$ to a depth of about $2 m$. There is evidence of low resistive region inferred as clayey material at the horizontal distances of $11-90 \mathrm{~m}$, at a depth of $5 \mathrm{~m}$ to $6 \mathrm{~m}$, and according to Urish [18], high contaminant is suspected. An intermediate zone with resistivity range from 55 to $200 \Omega m$ at a depth of 6 and $15 \mathrm{~m}$ which is part of the weathered zone but it is lateritic The contaminant plume may not be able to seep through it because of its impermeable nature. The resistivity value of $232 \Omega m$ was observed at a depth of $20 \mathrm{~m}$ which indicates fresh rock material without any structural pattern like faults.

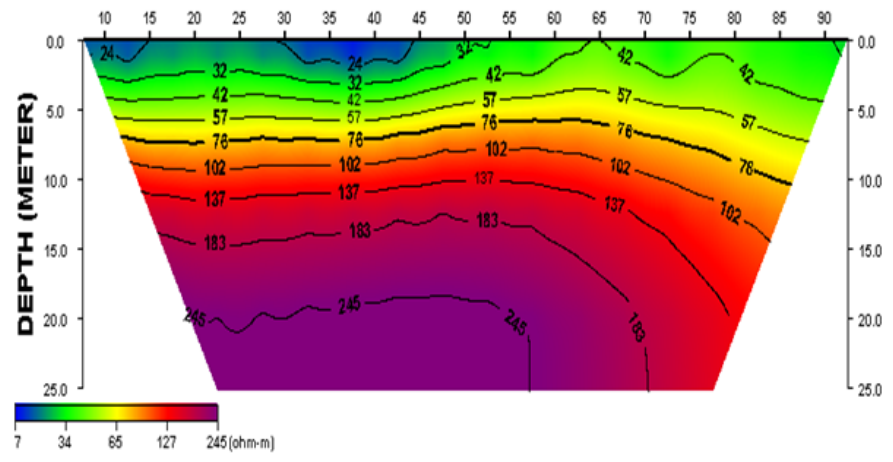

Figure 5. 2-D Electrical resistivity pseudosection for profile 3.

Figure 6 shows profile 4 the control, with a low resistivity value between $11 \Omega m$ and $20 \Omega m$ at the surface with a thin depth at a horizontal distance of $30-45 \mathrm{~m}$ and $105 \mathrm{~m}$ to $125 \mathrm{~m}$. The uppermost layer is underlain with resistivity range values from 50 to $170 \Omega m$ at a depth of 4 to $7 \mathrm{~m}$ which is part of the weathered zone but it is lateritic. The compacted lateritic clay outcrop at the surface between $55 \mathrm{~m}$ and $110 \mathrm{~m}$ as observed in the field during data acquisition. The compacted lateritic clay will not allow the plume to percolate through it to affect the subsurface beyond the surface layer. Any plume around this area will flow to nearby streams or to another region where it can percolate to the subsurface. A very high resistivity value of $400 \Omega \mathrm{m}$ and above, at a depth of $12 \mathrm{~m}$ was recorded and interpreted as a fresh rock material. This is so because, this profile is $200 \mathrm{~m}$ far away from the dumpsite unlike other profiles that are within the dumpsite. The contaminant at profile 2 is limited to the topsoil; a high contaminant is suspected at profile 3 , in profile 5 , the topsoil has very low resistivity values due to contamination from the plume that seeps out of the waste and saturated it. This shows a significant water quality variation with increasing distance from the dumpsite. 




Figure 6. 2-D Electrical resistivity pseudosection for profile 4.

Figure 7 presented profile 5 with resistivity values between $16-40 \Omega m$ at the topsoil. The topsoil has very low resistivity values due to contamination from the plume that seeps out of the waste and saturated it. Underlies this layer is a zone with resistivity range from 50 to $200 \Omega m$ at a depth of 5 to $9 m$ which is part of the weathered zone but it is lateritic. The compacted lateritic clay serves as seals for the subsurface aquiferous zone if exist around the area and will not allow percolation of the plume to the subsurface. A very high resistivity value of $240 \Omega \mathrm{m}$, at a depth of $10 \mathrm{~m}$ was recorded and interpreted as a fresh rock material. Resistivity distributions observed at greater depth are high when compared with low resistivity values observed at the surface. The uneven surface of the basement rock is as a result of weathering which has affected the hard rock.

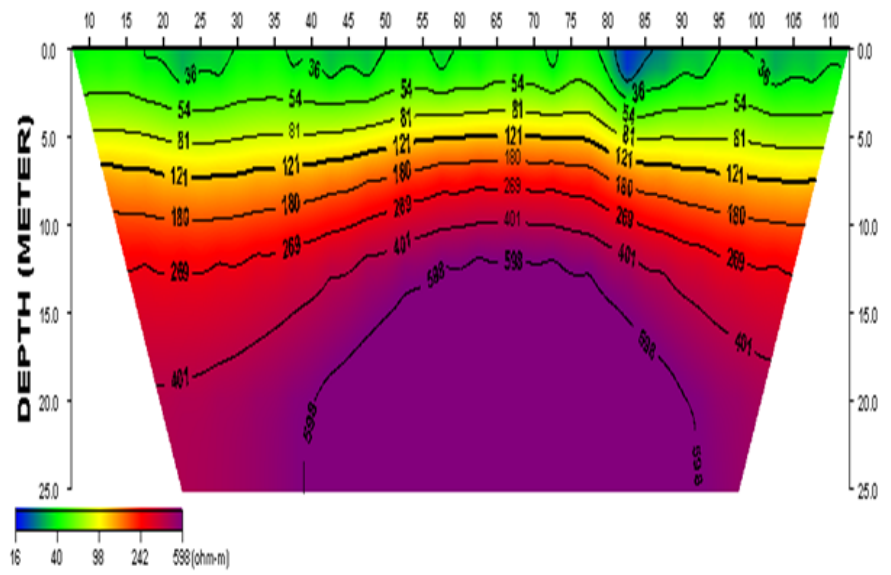

Figure 7. 2-D Electrical resistivity pseudosection for profile 5.

Results of the geochemical method are discussed below starting with the presentation of soil analysis as shown in Table 1.

\subsection{Discussion on Geochemical Analysis}

\subsubsection{Soil Sample Analysis}

The results of the sieve analysis show that the dominant lithology was sand. As depicted in Table 1, the soil at Akanran on-the-spot (onsite) has $66.6 \%$ of sand while the soil at location away from the site (offsite) which serves as the control has $81.1 \%$ of sand indicating an abundance of loosely soil particles. The silt content for onsite is $14.6 \%$ while the offsite is $9.27 \%$. The clay content shows $18.8 \%$ onsite and $9.61 \%$ offsite, a relatively low content interpreted as low protective capacity which confirmed easy migration of the plumes/leachate. Other properties include soil $\mathrm{pH}$, total porosity, bulk density, and hydraulic conductivity. The mean $\mathrm{pH}$ value of the soil samples for onsite is 6.4 (greater than that of the control) near the values of the work of Ewemoje et al. [19] with $\mathrm{pH}$ values ranging between 6.5 and 7.5. The mean $\mathrm{pH}$ value recorded for offsite in this work is 5.9 .

As the sand becomes increasingly clayey with depth at the offsites which stand for the control, fluids in the intergranular pores spaces are displaced, thereby increasing the bulk density with an average value of $1.62 \mathrm{~g} / \mathrm{cm}^{3}$ indicating a reduction in permeability from the topsoil down the depth but at the onsite, the bulk density is lower with average values of $1.37 \mathrm{~g} / \mathrm{cm}^{3}$. Therefore, with $9.61-18.8 \%$ clay, $9.27-19.7 \%$ silt, and an average bulk density of 1.48 (relatively high for a sandy loam) one can say that infiltration of the leachate will be minimal. The soil porosity at the onsite and offsite of the dumpsite ranges from 39 to $48.2 \%$ which could be considered high but, that of the offsites (control) is higher. The hydraulic conductivity of $2.58 \mathrm{~cm} / \mathrm{hr}$ at the onsite and also $3.0 \mathrm{~cm} / \mathrm{hr}$ at the offsites are considerably low but, that of the control is higher because of the distance is far away from the dumpsite.

\subsubsection{Water Sample Analysis}

Table 2 shows the results of the presentation of water analysis. The concentration of Enterococci levels (E coli) (cfu/100 $m l)$ in the water samples of Akanran dumpsite is shown in Table $2(0.45 \mathrm{ml})$ which exceeds the permissible level (20) limit of $0.00 \mathrm{ml}$ and indicating the presence of an anomaly in the body of water at minimal concentrations but, for the control sample, the value is less $(0.03 \mathrm{ml})$. The $\mathrm{pH}$ of the water sample analysis obtained is 6.9, suggesting acidic concentrates in the groundwater of the study area. However, this $\mathrm{pH}$ value fall within the permissible level (20) of $6.5-8.5$ for potable water shows that the groundwater in the study area is suitable for drinking although the control sample value is 6.45. The Total Organic Carbon (TOC) with a value of $2.14 \mathrm{mg} / \mathrm{l}$ is less than the control sample value of $0.67 \mathrm{mg} / \mathrm{l}$ and NIS, 2007 recommended value of $5.00 \mathrm{mg} / \mathrm{l}$. The Total Dissolved solid (TDS) is $224.1 \mathrm{mg} / \mathrm{l}$. while that of the control sample is half of the value $(112 \mathrm{mg} / \mathrm{l})$ and the permissible level (20) limit of $500 \mathrm{mg} / \mathrm{l}$, hence the water is suitable for drinking and also for domestic purposes (Fig. 8).

Nitrate level in the study area is $2.56 \mathrm{mg} / \mathrm{l}$ and it leaches into the groundwater in the form of nitrate. Nitrate is not a threat to health issues unless it is reduced to nitrite of high concentrations but in this study, nitrate levels in the water samples are within the permissible level (20) limit of $50.0 \mathrm{mg} / \mathrm{l}$ and the nitrite level was $0.09 \mathrm{mg} / \mathrm{l}$ (greater than the control sample value of 0.03 ) which is moderate when compared to the NIS permissible level (20) limit of $0.20 \mathrm{mg} / \mathrm{l}$. This suggests that the groundwater in the area of the survey is safe. The chemical oxygen demand (COD) of $167.1 \mathrm{mg} / \mathrm{l}$ is higher than the permissible level (20) of $150 \mathrm{mg} / \mathrm{l}$ and does pose a minimal threat. But, the control sample value of $92.0 \mathrm{mg} / \mathrm{l}$ is less than the permissible level and is very safe water quality in the control sample area because, it is far from the dumpsite location. 
Table 1. Results of soil Analysis [Treatments with the same letter(s) in each property do not differ significantly $(P<0.05)$; NS indicates not significant at a $5 \%$ level. CV \%: Coefficient of variation].

\begin{tabular}{lccccccc}
\hline Treatment & $\begin{array}{c}\text { pH } \\
\left(1: 1 \mathrm{H}_{2} \mathrm{O}\right)\end{array}$ & $\begin{array}{c}\text { Sand } \\
(\%)\end{array}$ & $\begin{array}{c}\text { Silt } \\
(\%)\end{array}$ & $\begin{array}{c}\text { Clay } \\
(\%)\end{array}$ & $\begin{array}{c}\text { BD } \\
g / \mathrm{cm}^{3}\end{array}$ & $\begin{array}{c}\text { TP } \\
(\%)\end{array}$ & $\begin{array}{c}\text { Ks } \\
(\mathrm{cm} / \mathrm{hr})\end{array}$ \\
\hline Akanran Onsite & 6.4 & 66.6 & 14.6 & 18.8 & 1.37 & 48.2 & 2.58 \\
Akanran Offsite & 5.9 & 81.1 & 9.27 & 9.61 & 1.62 & 39.0 & 3.00 \\
Depth & & & & & & & \\
$0-2 \mathrm{~cm}$ & $6.3 \mathrm{NS}$ & $70.5 \mathrm{NS}$ & $14.2 \mathrm{NS}$ & $15.3 \mathrm{NS}$ & $1.48 \mathrm{NS}$ & $44.0 \mathrm{NS}$ & $2.36 \mathrm{NS}$ \\
$20-40 \mathrm{~cm}$ & 6.2 & 70.9 & 13.6 & 15.5 & 1.48 & 44.2 & 2.16 \\
CV\% & 4.0 & 3.0 & 20.4 & 12.5 & 1.2 & 1.5 & 24.6 \\
\hline
\end{tabular}

Table 2. Results of Water Analysis [LSD: Least Significant Difference].

\begin{tabular}{lcccc}
\hline $\begin{array}{l}\text { Test Elements } \\
(\mathrm{mg} / \mathrm{l})\end{array}$ & $\begin{array}{c}\text { Hand Dug } \\
\text { Wells }\end{array}$ & $\begin{array}{c}\text { Control } \\
\text { Value }\end{array}$ & $\begin{array}{c}\text { LSD } \\
(P<0.05)\end{array}$ & $\begin{array}{c}\text { Permissible } \\
\text { Level }(\mathbf{2 0})\end{array}$ \\
\hline E. coli $(\mathrm{cfu} / 100 \mathrm{ml})$ & 0.45 & 0.03 & 1.61 & 0.00 \\
Total Organic Carbon & 2.14 & 0.67 & 3.06 & 5.00 \\
Total Dissolved Solids & 224.1 & 112 & 314.9 & 500.0 \\
Nitrate $\left(\mathrm{NO}_{3}\right)$ & 2.56 & 1.22 & 2.90 & 50.0 \\
Nitrite $\left(\mathrm{NO}_{2}\right)$ & 0.09 & 0.03 & 0.14 & 020 \\
Chemical Oxygen Demand & 167.1 & 92 & 217.9 & $<150.0$ \\
pH & 6.9 & 6.45 & 1.2 & $6.5-8.5$ \\
Sodium $(\mathrm{Na})$ & 3.44 & 2.43 & 1.98 & 200.0 \\
Sulphate $\left(\mathrm{SO}_{4}\right)$ & 4.88 & 3.35 & 1.71 & 100.0 \\
Zinc $(\mathrm{Zn})$ & 1.81 & 1.24 & 1.34 & 3.00 \\
Copper $(\mathrm{Cu})$ & 0.38 & 0.08 & 0.57 & 1.00 \\
Lead $(\mathrm{Pb})$ & 0.21 & 0.02 & 0.76 & 0.01 \\
Chromium $(\mathrm{Cr})$ & 0.003 & 0.001 & 0.006 & 0.005 \\
\hline
\end{tabular}

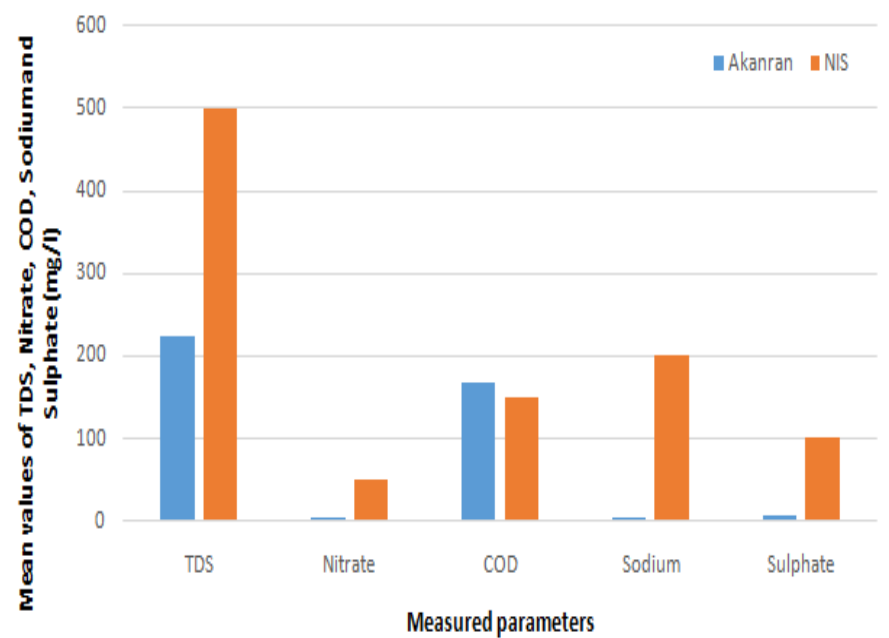

Figure 8. The mean values for TDS, Nitrate, COD, Sodium, and Sulphate against NIS values.

The concentrations of sodium ion $\left(\mathrm{Na}^{+}\right)$and sulphate ion $\left(\mathrm{SO}_{4}^{2-}\right.$ ) for Akanran dumpsite is 3.44 and $4.88 \mathrm{mg} / \mathrm{l}$ and relatively low when compared to their permissible level limit of 200 and $100 \mathrm{mg} / \mathrm{l}$, respectively [20]. Sodium saturated soils are not healthy to plant growth according to Davis and De Wiest [21].

The concentration of heavy metals in well sample from Akan-

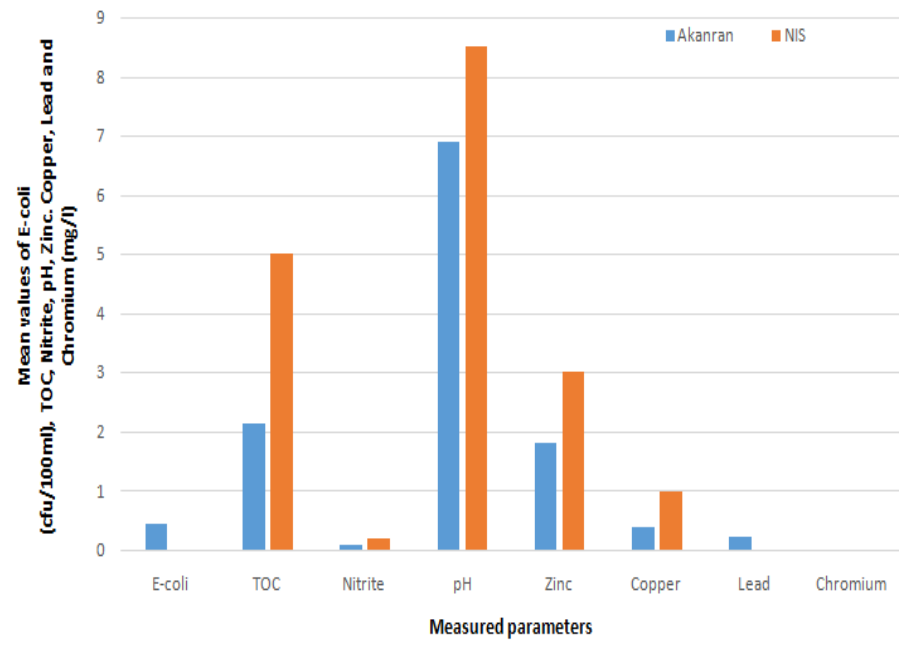

Figure 9. The mean values for E-coli, TOC, Nitrite, $\mathrm{pH}$, Zinc, Copper, Lead and Chromium against NIS values.

ran dumpsite were $\mathrm{Zn}(1.81 \mathrm{mg} / \mathrm{l}), \mathrm{Cu}(0.38 \mathrm{mg} / \mathrm{l}), \mathrm{Pb}(0.21$ $m g / l), \operatorname{Cr}(0.003 \mathrm{mg} / l)$ (Fig. 9). Results obtained for lead shows a high concentration value above the recommended value of $0.01 \mathrm{mg} / \mathrm{l}$ [21]. According to USDA [22], heavy metals occur naturally, but rarely at toxic levels. The above listed heavy metals concentration values are below the recommended values of the Standard Organisation of Nigeria (SON) [20], including the 
control sample values except for Lead metal although, the control sample value of $0.02 \mathrm{mg} / \mathrm{l}$ is approximately the same with the permissible level without any hazard. The high concentration of lead in the study area could be due to the presence of waste containing fuel and engine oil in the dumpsite.

\section{Conclusion}

The effect of Akanran dumpsite on groundwater quality for drinking and domestic purposes is minimal. The results of the 2-D resistivity survey give resistivity value of $9.2 \Omega \mathrm{m}$ indicating the presence of leachate. The extent is within the topsoil, an indication that the underlying layer has a greater risk of contamination by leachate and decomposed solid waste materials. However, the geochemical results also shown possible contamination with time.

The $\mathrm{pH}$ of the water sample analysis obtained is 6.9 , suggesting acidic concentrates in the groundwater of the study area. However, this $\mathrm{pH}$ value for drinking water is within the permissible level of $6.5-8.5$ indicating that the groundwater in the study area is suitable for drinking, domestic purpose and agricultural use; and there is high toxicity level and possible leaching of lead. Hence, the combined techniques gave a better understanding of the study area than using a single investigative method.

It is hereby recommended that a periodic study of the dumping site be done annually as the age of dumpsite affects significantly the quantity of leachate formed. It is also recommended to know the effect of depth on leachate concentration and chemical constituents of water samples to ascertain the nature of pollutants.

\section{Acknowledgments}

The authors hereby acknowledged the people of Akanran village for their support during the field work. The authors also wish to thank the referees for the positive enlightening comments and suggestions, which have greatly helped us in making improvements to this paper.

\section{References}

[1] G. J. Farquhar, "Leachate: Production and Characterization" Canadian Journal of Civil Engineering, 16 (1989) 317.

[2] W. J. Schneider, "Hydrological Implications of Solid Waste Disposal" U.S. Geological Survey, (1970) 12.
[3] M. A. Oladunjoye, A. I. Olayinka \& S. A. Amidu, "Geoelectrical Imaging at an Abandoned Waste Dumpsite in Ibadan, South-western Nigeria" Journal of Applied Sciences, 11 (2011) 755.

[4] E. Martinho \& F. Almeida, "3D behavior of contamination in landfill site using 2D resistivity/IP Imaging. Case studies in Portugal” Env. Geol. 49 (2006) 1070.

[5] J. M. Reynolds, "An introduction to applied and Environmental geophysics" John Wiley \& Sons Ltd (1997).

[6] R. A. Foster, "Getting to grips with groundwater pollution protection in developing countries" National Resour. Forum 10 (1986) 51.

[7] B. Jimenez, "Coming to term with nature: Water reuse new paradigm towards integrated water resources management Encyclopedia of Biological, Physiological and Health Sciences", Water and Health, Vol.II: Life Support System, (2009) 398.

[8] H. Yadav, P. Kumar \& V. P. Singh, "Hazards from the Municipal Solid Waste Dumpsites" A Review. Proceedings of the 1st International Conference on Sustainable Waste Management through Design (2018) 336.

[9] J. R. Yoon, K. Lee, B. D. Kwon \& W. S. Han, "Geoelectrical Surveys of the Nanjido Waste landfill in Seoul, Korea" Env.Geology, 43 (2003) 654.

[10] I. B. Osazuwa \& N. K. Abdullahi, "2D Electrical Resistivity and Induced Polarization investigation at an open solid waste dumpsite: A case study from Kaduna, North Central Nigeria" Journal of Environmental Hydrology 16 (2008) 1.

[11] NGSA, "Nigeria Geological Survey Agency" Nigeria (2010).

[12] S. A. Ganiyu, B. S. Badmus, O. A. Idowu, M. A. Oladunjoye \& O. T. Olurin, "2D Electrical Resistivity Imaging Investigation of Open Dump Site in Basement Complex Formation" The African Review of Physics 10 (2015) 0033

[13] O. A. Okunlola, O. C. Adeigbe \& O. O. Oluwatoke, "Compositional and petrogenetic features of Schitose rocks of the Ibadan area, South-western Nigeria" Earth Sciences Research Journals 13 (2009) 29.

[14] J. O. Coker, "Vertical electrical sounding (VES) methods to delineate potential groundwater aquifers in the Akobo area, Ibadan, South-western, Nigeria" Journal of Geology and Mining Research 4 (2012) 35.

[15] B. S. Badmus, V. C. Ozebo, O. A. Idowu, S. A. Ganiyu \& O. T. Olurin, "Physico-Chemical Properties of Soil Samples and Dumpsite Environmental Impact on Groundwater Quality in South Western Nigeria" African Review of Physics 9 (2014) 103.

[16] A. O. Ohwoghere, F. I. Chiyem \& H. O. Nwankwoala, "2D Resistivity Electrical Imaging of Unsaturated and Saturated Zones for Crude Oil Spillage at Agbarha in Ughelli Area of Delta State Nigeria" Technical Report (2014).

[17] R. B. Grossman \& T. G. Reinsch, "Bulk density and Linear extensibility" Soil Science Society of America (2002) 201.

[18] D. W. Urish, "The practical application of surface electrical resistivity to the detection of groundwater pollution" J. Ground Water 21 (1983) 144.

[19] T. A. Ewemoje, O. E. Ewemoje \& S. P. Majolagbe, "Urbanisation Effects on Surface and Groundwater Resources: An Assessment of Approved Dumpsite in Ibadan, Nigeria". An ASABE Meeting Presentation (2017) DOI: 10.13031/aim.201701388.

[20] Standard Organisation of Nigeria (SON), Nigerian Standard for Drinking Water Quality. NIS 554 (2007) 30.

[21] S. Davis \& R. De Wiest, "Hydrogeology" John Wiley \& Sons, New York (1996).

[22] USDA Diagnosis and Improvement of Saline and alkali soils U.S. Salinity Laboratory Staff, Government Printing Office, Washington, D.C. (2000). 